\title{
Aerobic and anaerobic mineralization of Salvinia molesta and Myriophyllum aquaticum leachates from a tropical reservoir (Brazil)
}

\author{
Mineralização aeróbia e anaeróbia dos lixiviados de Salvinia molesta e \\ Myriophyllum aquaticum de um reservatório tropical (Brasil)
}

Renato Henriques da Silva ${ }^{1,2}$, Rafael Spadaccia Panhota ${ }^{3}$ and Irineu Bianchini Junior ${ }^{1,3}$

${ }^{1}$ Departamento de Hidrobiologia, Universidade Federal de São Carlos,

Rod. Washington Luis, km 235, CP 676, CEP 13565-905, São Carlos, SP, Brazil

e-mail: renatohenriques@gmail.com, irineu@ufscar.br

${ }^{2}$ Département des Sciences Biologiques, Université du Québec à Montréal - UQÀM,

141 Avenue du Président-Kennedy Montréal, Québec, H2X 1Y4, Canadá

e-mail: henriques_da_silva.renato@courrier.uqam.ca

${ }^{3}$ Programa de Pós Graduação em Ecologia e Recursos Naturais, Universidade Federal de São Carlos - UFSCar,

Rod.Washington Luis, km 235, CP 676, CEP 13565-905, São Carlos, SP, Brazil e-mail: rafaelspadaccia@hotmail.com

\begin{abstract}
Aim: This study aimed at describing and discussing the leachates mineralization (aerobic and anaerobic) of two species of aquatic macrophytes (Salvinia molesta and Myriophyllum aquaticum) from a tropical reservoir $\left(22^{\circ} 00^{\prime} \mathrm{S}\right.$ and $\left.47^{\circ} 54^{\prime} \mathrm{W}\right)$; Methods: The incubations were prepared with plant leachates and reservoir water sample and were maintained during 45 days in the dark (at $20^{\circ} \mathrm{C}$ ). The organic carbon and the oxygen consumption kinetics were evaluated; Results: Irrespective of to the experimental condition, the leachates were mainly utilized for catabolic processes (i.e., respiration), mineralization was slightly faster in an aerobic environment ( 1.22 fold $)$ and in this condition, the yield of refractory products was smaller (2.3\%); the $\mathrm{O} / \mathrm{C}$ stoichiometric ratios values (oxygen consumed per atom of carbon) from mineralization of the 2 types of leachates were similar (ca. 1.12); Conclusions: According to these results we conclude that the leachate from selected macrophytes is rapidly decomposed and subsidize primariy the microbial catabolism (aerobic or anaerobic); in addition, we propose that $S$. molesta contributes more to the input of dissolved organic matter within the reservoir.
\end{abstract}

Keywords: aquatic macrophytes, mineralization kinetics, leachate, oxygen consumption, Monjolinho Reservoir.

Resumo: Objetivo: Nesse estudo foram descritas as mineralizaçōes (aeróbias e anaeróbias) dos lixiviados de 2 espécies de macrófitas aquáticas (Salvinia molesta e Myriophyllum aquaticum) que ocorrem em um reservatório tropical $\left(22^{\circ} 00^{\prime} \mathrm{S}\right.$ e $47^{\circ} 54^{\prime} \mathrm{O}$ ); Métodos: As incubaçóes, preparadas com os lixiviados das plantas e amostra de água do reservatório, foram mantidas no escuro e a $20^{\circ} \mathrm{C}$, por 45 dias. Foram avaliadas as cinéticas de perda de massa do carbono orgânico e de consumo de oxigênio; Resultados: Independente da condição experimental, os lixiviados foram principalmente utilizados na respiração; as mineralizaçôes foram ligeiramente mais rápidas em meio aeróbio ( 1,22 vezes) e nessa condiçáo, os rendimentos dos produtos refratários foram menores (2,3\%); as relaçóes estequiométricas $\mathrm{O} / \mathrm{C}$ (oxigênio consumido por átomo de carbono) foram similares nas mineralizaçôes aeróbias dos dois tipos de lixiviado $(\approx 1,12)$; Conclusóes: Com base nesses resultados concluiu-se que os lixiviados das macrófitas selecionadas são rapidamente decompostos e subsidiam prioritariamente o catabolismo (aeróbio ou anaeróbio) microbiano; supôs-se, ainda, que S. molesta contribua mais para as aduçóes de matéria orgânica dissolvida do reservatório do Monjolinho.

Palavras-chave: macrófitas aquáticas, cinéticas de mineralização, lixiviado, consumo de oxigênio, reservatório do Monjolinho. 


\section{Introduction}

Due to their large geographic distribution and elevated growth rates, aquatic macrophytes may be important to many ecological processes, such as i) trophic chains (e.g., support molluscs and insects), ii) nutrient cycling and iii) energy flux through aquatic ecosystems. Within lentic environments in tropical climate, these organisms usually encounter favorable conditions (e.g., high temperatures and solar irradiances) for their development (Camargo and Esteves, 1995). Moreover, water eutrophication due to sewage (domestic and industrial) and input of agricultural nutrients intensify the growth of these vegetables (Penning et al., 2008). In these circumstances, aquatic plants may comprise a large proportion of the littoral zone biomass and therefore should be considered an important source of detritus production (Bianchini Junior, 2003). The decomposition of these organisms can be divided into three main events: i) leaching (the release of hydrosoluble compounds, such as simple sugars, proteins and nutrients (Bastardo, 1981), which produces, during the firsts steps of the process, great quantities of dissolved organic matter; ii) the physical fragmentation of the detritus and the chemical modifications due to digestion process; and iii) catabolism of structural components (e.g., leachates, fibres). During the aerobic decomposition, aquatic plant leachates are mainly utilized in biochemical processes related to energy production; although they may also contribute significantly to microorganism growth (Peret and Bianchini Junior, 2004). The degradation of particulate organic matter, which is composed by fibres (i.e., lignin, hemicelluloses and cellulose), is mainly conducted by enzymatic reactions, which are responsible for the conversion of complex organic compounds; this is usually the longer phase (Nunes et al., 2011). The processes responsible for the decomposition depend on the composition and number of associated organisms, the physical and chemical properties of the medium (e.g., temperature, $\mathrm{pH}$, salinity, concentrations of nutrients and dissolved oxygen), the detritus quality and on the size of the particles (Swift et al., 1979; Wetzel, 2001).

Due to environmental conditions and organisms involved in the decomposition, intermediary organic products of the catabolism can be resynthesized, incorporated into the biomass of organisms or converted to non-cellular compounds such as: the products of excretion and humic substances (Stoderegger and Herndl, 1998;
Wetzel, 2001). While these processes, which are denominated as immobilization, maintain the decomposition products in an organic form (Swift et al., 1979), mineralization converts detritus organic components into inorganic molecules and comprises both chemical and biochemical reactions. Thus, energy flux dynamics and the velocity in which the nutrients are accumulated and recycled depend up on the balance of immobilization and mineralization processes. As aquatic macrophytes are important sources in the maintenance of the detritus chain in lentic aquatic environments, this study aimed to describe the kinetic aspects of leachate mineralization (aerobic and anaerobic) of Salvinia molesta and Myriophyllum aquaticum, species that occur in the Monjolinho Reservoir.

\section{Material and Methods}

\subsection{Study area}

The Monjolinho Reservoir is a small artificial water system located at São Carlos (São Paulo State, Brazil; $22^{\circ} 00^{\prime} \mathrm{S}$ and $\left.47^{\circ} 54^{\prime} \mathrm{W}\right)$. The maximum depth is $3 \mathrm{~m}$, the flooded area comprises $41,157 \mathrm{~m}^{2}$ and the reservoir has a volume of $73,251 \mathrm{~m}^{3}$ (Nogueira and Matsumura-Tundisi, 1994); its hydraulic retention time varies between 2 and 23 days, depending on the season (Cunha-Santino and Bianchini Junior, 2003). Monjolinho stream provides waters to the reservoir, the anthropic pressures on this watershed affect the water quality of this ecosystem (Marinelli et al., 2000). Aquatic macrophytes occur mainly at the littoral zones where the following species are currently found: Myriophyllum aquaticum, Salvinia molesta and Spirodela sp.

\subsection{Selected macrophytes features}

The genus Myriophyllum (Haloragaceae) is among the most species rich ( $\approx 68$ species) of the aquatic core-eudicots (Moody and Les, 2010). These plants have three types of stems: emergent, floating or formed from rhizome. The leaves are pectinate and are arranged in whorls in numbers in 4 or 6 whorls. During the emergence from shallow waters the stem has a rigid consistency with velvety surfaced leaves (Notare, 1992). Myriophyllum aquaticum, commonly known as "parrotfeather", is a plant of stagnant or slow moving water, which can be found in shallow waters rooted with emergent stems or over deep water with floating stems (Orchard, 1981). To date, Myriophyllum aquaticum (Vell.) Verdc has been introduced across many regions of 
the world, so much so that it is now considered a nuisance in many locations (Notare, 1992, Hussner et al., 2009).

The genus Salvinia (Salvniaceae) posses a floating stem that has irregular ramifications and lacks roots, being characterized by leaves arranged in whorls. Salvinia molesta D. S. Mitchell, specifically, has a great capacity to rapidly colonize the limnetic zone due to its elevated growth rates and vegetative reproduction. This species posses three growth forms: i) the "primary-invading form" is produced when the species invades an area for the first time and is characterized by small leaves $(\approx 1.5 \mathrm{~cm}$ width) that float on the waters surface; ii) the "open-water colonizing form" has $2 \mathrm{~cm}$ width boat-shape leaves where the whole bottom surface is in contact with the water; iii) the "mat form" is produced during competition for space, the plants becoming compressed, robust and having $6 \mathrm{~cm}$ width floating leaves (Mitchell and Tur, 1975). Normally, this is the only form to bear sporocarps. Many different specific growth rates were registered for $S$. molesta and the density can constitute the main limiting factor (Henry-Silva et al., 2008). Chemical analyses performed on this species indicated the following composition (based on dry matter): protein $=8.7 \%$, phosphorus $=0.26 \%$, polyphenols $=0.37 \%$, cell wall fraction $=68.2 \%$, lipids $=3.8 \%$ and soluble carbohydrates $=1.3 \%$ (Silva, 2001).

\subsection{Sampling and incubations set up}

In August 2005, S. molesta and M. aquaticum were collected within the backwater region of the reservoir. In the laboratory, the plants were washed with tap water, dried $\left(50^{\circ} \mathrm{C}\right)$ until constant mass, powdered and the fragments were autoclaved (15 min, $1 \mathrm{~atm}$ and $121{ }^{\circ} \mathrm{C}$; Ward and Johnson, 1996).

The leachates were obtained by aqueous extraction. Thus, plant fragments and distilled and sterilized water $\left(10 \mathrm{~g}\right.$ (dry mass). $\left.\mathrm{L}^{-1}\right)$ were kept 24 hours at $4{ }^{\circ} \mathrm{C}$ (M $\phi$ ller et al., 1999). To obtain dissolved fractions, the extracts were filtered through a $0.45 \mu \mathrm{m}$ ester cellulose membrane.

To evaluated the kinetics of the processes involved in the leachates mineralization (mass loss and oxygen consumption), for each leachate type and experimental condition (aerobic and anaerobic), 2 incubations (vol.: $300 \mathrm{~mL}$ ) containing leachate extracts diluted with reservoir water samples (previously filtered with a $1.2 \mu \mathrm{m}$ glass fiber - Whatman) were prepared with a concentration ca. of $100 \mathrm{mg} . \mathrm{L}^{-1}$ on organic carbon basis; the organic carbon concentration was measured by a carbon analyzer (Shimadzu, model TOC-5000A). 2 Control flasks (containing just reservoir water sample filtered with a $1.2 \mu$ m glass fiber - Whatman) were also prepared. The water sample $(\approx 10 \mathrm{~L})$, which was utilized as a source of microorganisms for incubation as well to dilute leachates, was collected in September 2005, in the same region where the plants were previously sampled. The solutions ( $\mathrm{n}=12$ ) kept in aerobic conditions (i.e., 6 to measure the carbon concentration and 6 to measure the dissolved oxygen concentration) were aerated with filtered clean air until dissolved oxygen (DO) reached saturation concentration (ca. 1 hours); during the experiment, this procedure was repeated whenever DO attained $\approx 2.0 \mathrm{Mg} \cdot \mathrm{L}^{-1}$. To obtain and maintain solutions in anaerobic conditions $(\mathrm{n}=6)$, the solutions were bubbled with nitrogen (ca. $45 \mathrm{~min}$ ). The solutions were then incubated ( 45 days) in the dark at $20^{\circ} \mathrm{C}$. Samples (ca. $3.0 \mathrm{~mL}$ ) were taken from each flask (days: 0, 1, 2, 3, 4, 6, 7, $8,9,12,15,30$ and 45) and carbon (organic and inorganic) concentrations were determined through combustion and detection in infrared (Shimadzu, model TOC - 5000A) whereas DO was measured periodically with dissolved oxygen meter (YSI, model 58), in specific flasks ( $\mathrm{n}=6 ; 2$ to each leachate type and 2 control).

\subsection{Equations}

First order kinetic models were employed to fit the total organic carbon (TOC) concentration and consumed oxygen (OC) and to determine the mass loss coefficient for the leachates organic carbon $\left(\mathrm{k}_{\mathrm{T}}\right)$ and for the oxygen consumption $\left(\mathrm{k}_{\mathrm{D}}\right)$, respectively (Peret and Bianchini Junior, 2004). Parameterizations of models were performed by non-lineal regression, using an iterative method (Levenberg-Marquardt algorithm; Press et al., 1993). Equations 1 to 6 represent these models.

Global mass loss:

$\frac{\mathrm{d}[\mathrm{TOC}]}{\mathrm{dt}}=-\mathrm{k}_{\mathrm{T}}[\mathrm{TOC}]$

where TOC $=$ total organic carbon concentration; $\mathrm{k}_{\mathrm{T}}=$ total mass loss coefficient $\left(=\mathrm{k}_{1}+\mathrm{k}_{2}\right)$, day ${ }^{-1}$; $\mathrm{k}_{1}=$ labile fraction mineralization coefficient (e.g., sugars, polyphenols, glycosides), day $^{-1} ; \mathrm{k}_{2}=$ coefficient of organic refractory compound production (e.g., humic compounds, microorganisms), day ${ }^{-1}$.

Labile fraction mineralization: 
$\frac{\mathrm{d}\left[\mathrm{IN}_{1}\right]}{\mathrm{dt}}=\mathrm{k}_{\mathrm{T} \mathrm{y}_{1}}[\mathrm{TOC}]$

where: $\mathrm{y}_{1}=\frac{\mathrm{k}_{1}}{\left(\mathrm{k}_{1}+\mathrm{k}_{2}\right)}=$ labile fraction mineralization yield in proportion to the total mass loss; $\mathrm{IN}_{1}=$ inorganic compounds production by labile compound mineralization route; $\mathrm{t}=$ time (days).

Formation and mineralization of the refractory organic carbon fractions (ROC):

$\frac{\mathrm{d}[\mathrm{ROC}]}{\mathrm{dt}}=\mathrm{k}_{\mathrm{Ty}}[\mathrm{TOC}]-\mathrm{k}_{3}[\mathrm{ROC}]$

ROC mineralization:

$\frac{\mathrm{d}\left[\mathrm{IN}_{2}\right]}{\mathrm{dt}}=\mathrm{k}_{3}[\mathrm{ROC}]$

where: $y_{2}=\frac{k_{2}}{\left(k_{1}+k_{2}\right)}=$ refractory fractions mineralization yield in proportion to the total mass loss; $\mathrm{IN}_{2}=$ inorganic compounds production by refractory compound mineralization route; $\mathrm{k}_{3}=$ refractory fractions mineralization, day ${ }^{-1}$.

Oxygen consumption:

$\frac{\mathrm{d}[\mathrm{DO}]}{\mathrm{dt}}=-\mathrm{k}_{\mathrm{D}}[\mathrm{DO}]$

where $[\mathrm{DO}]=$ dissolved oxygen concentrations (mg. $\left.\mathrm{L}^{-1}\right) ; \mathrm{k}_{\mathrm{D}}=$ deoxygenation coefficient $\left(\right.$ day $\left.^{-1}\right)$; $\mathrm{t}=$ time (days). Rather than [DO] the interest is the amount of oxygen used in the consumption (OC) of organic compounds.

$\mathrm{OC}_{\mathrm{MAX}}=[\mathrm{DO}]_{0}-[\mathrm{DO}]_{\mathrm{t}}$

where: $[\mathrm{DO}]_{0}=$ dissolved oxygen concentration at time $=0 ;[\mathrm{DO}]_{\mathrm{t}}$ are $=$ dissolved oxygen concentration at time $=\mathrm{t} ; \mathrm{OC}_{\mathrm{MAX}}=$ maximum amount of consumed oxygen; (mg. $\left.\mathrm{L}^{-1}\right)$.

The stoichiometric relationships $(\mathrm{O} / \mathrm{C})$ were calculated from the ratio of maximum amount of consumed oxygen $\left(\mathrm{OC}_{\mathrm{MAX}}\right)$ and the final amount of mineralized carbon (MC). The half-life times $\left(\mathrm{t}_{1 / 2}\right)$, from both mass loss and oxygen consumption processes for each leachate, was calculated according to Equation 7.

$\mathrm{t}_{1 / 2}=\frac{\ln 0.5}{-\mathrm{k}}$

where: $\mathrm{k}$ = reaction rate (mass loss or deoxygenation), day $^{-1}$.

\section{Results}

The leaching processes reduced the plant mass (hydrosoluble compounds) by approximately $14.4 \%$ for $S$. molesta and $9.4 \%$ for $M$. aquaticum.
The kinetics for leachate mass loss are presented in Figures 1 and 2. The effects of mineralization and oxygen consumption of the TOC from the control flasks were neutralized by subtracting the values from the enriched flasks. Table 1 presents the parameterizations for the kinetic models utilized. For both leachates (i.e., from S. molesta and $M$. aquaticum) the mass loss global coefficients were close. However, the coefficients $\left(\mathrm{k}_{\mathrm{T}}\right)$ from the aerobic processes $\left(0.21\right.$ and 0.20 day $^{-1}$ for $S$. molesta and $M$. aquaticum leachates, respectively) were slightly higher than the anaerobic conditions $(0.18$ and 0.20 day $^{-1}$ for $S$. molesta and $M$. aquaticum leachates, respectively), suggesting that aerobic processes tend to be slightly faster, which is also supported by the half-life times (Table 1). In all cases, catabolism (i.e., mineralization) was favored over the formation of refractory compounds; the MC yields were always higher than 90\%. All values of $r^{2}$ derived from the kinetic fits ranged between 0.93 (anaerobic mineralization S. molesta leachate) and 0.97 (aerobic mineralization S. molesta leachate).

The amount of dissolved inorganic carbon (DIC) yielded in the mineralization processes were different between the two types of leachates, being three times higher for $S$. molesta, in both aerobic and anaerobic processes (Table 1). From the total amount of MC, $13.0 \%$ (aerobic) and 12.5\% (anaerobic) remained in the form of DIC within the S. molesta leachate incubations whereas only $4.4 \%$ (aerobic) and 5.0\% (anaerobic) remained within the leachate $M$. aquaticum leachate incubations (Table 1).

The kinetic adjustments from the measurements of oxygen consumption that occurred during the mineralization processes are presented in Figure 2 ( $\mathrm{a}$ and $\mathrm{b})$. In Table 1 , the values of the parameters $\mathrm{OC}_{\mathrm{MAX}}$ and $\mathrm{k}_{\mathrm{D}}$ from the kinetic model adopted were related; moreover, the coefficient of determination $\left(\mathrm{r}^{2}\right)$ from the adjustments and the stoichiometric relationship between amount of oxygen consumed per oxidized carbon $\left(\mathrm{OC}_{\mathrm{MAX}} /\right.$ $\mathrm{MC})$ were also included. The values of $\mathrm{r}^{2}$ from OC fits were high (0.98 and 0.99). Finally, a small difference between the oxidative processes of S. molesta and M. aquaticum leachates was detected (Figures 1 and 2); however, in both cases, the overall pattern for oxygen consumption was similar, being more intense until the $20^{\text {th }}$ day and diminishing progressively, stabilizing at the final stage of the mineralization process. 

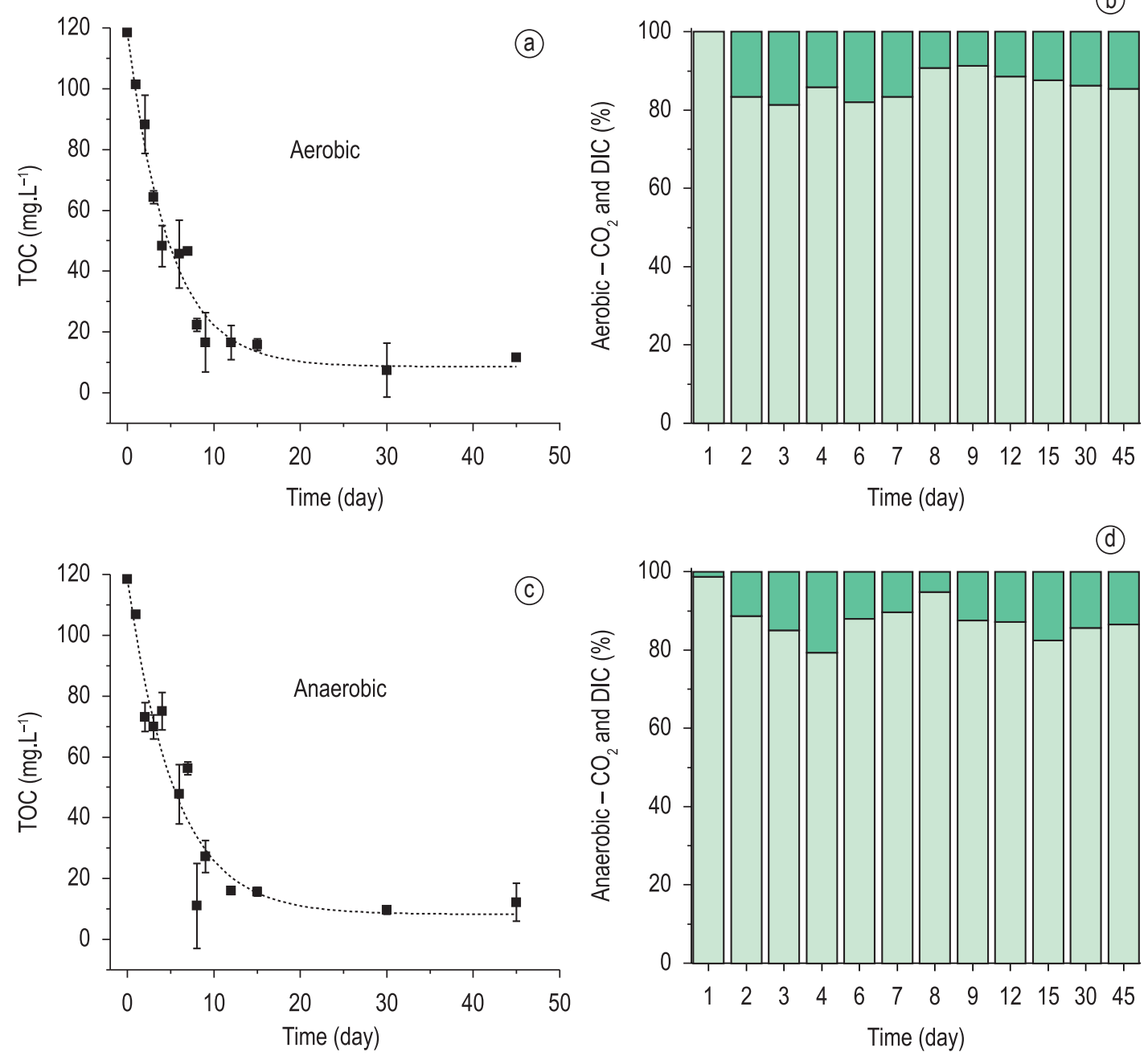

(e)

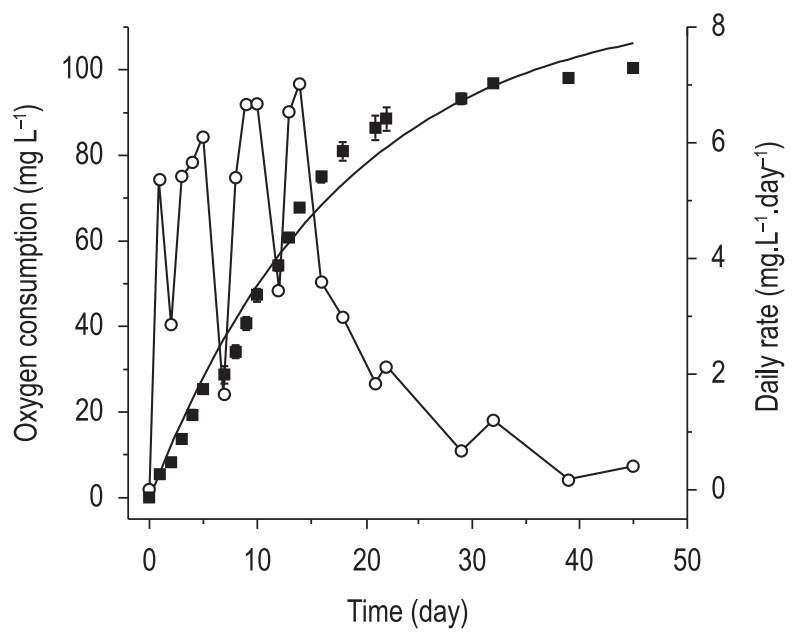

Figure 1. Kinetics of the Salvinia molesta leachate decreases (on organic and inorganic carbon basis) under aerobic $(\mathrm{A}, \mathrm{B})$ and anaerobic conditions $(\mathrm{C}, \mathrm{D})$. Daily rates and kinetic of oxygen consumption from aerobic decomposition of S. molesta leachate (E). 

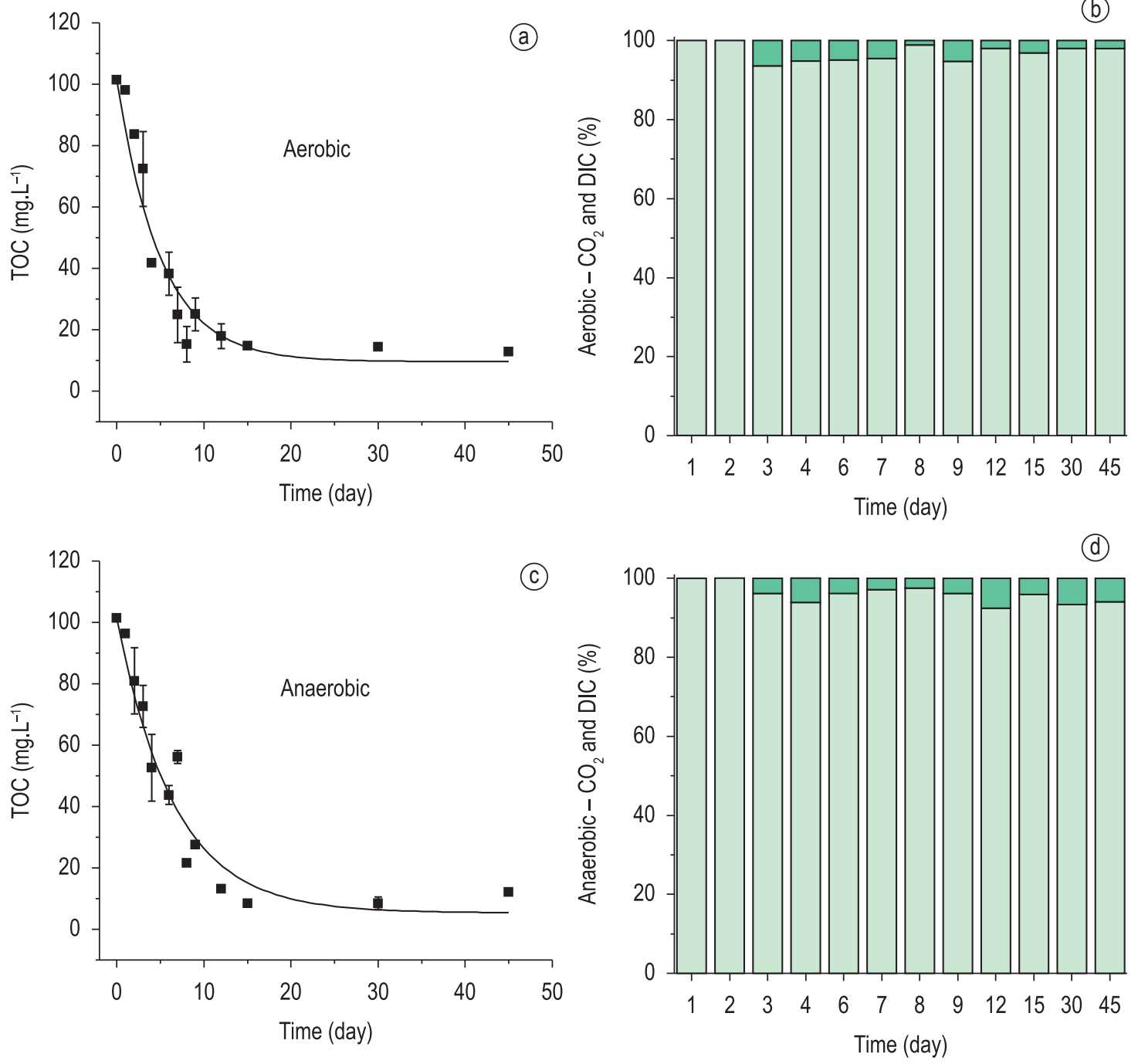

(e)

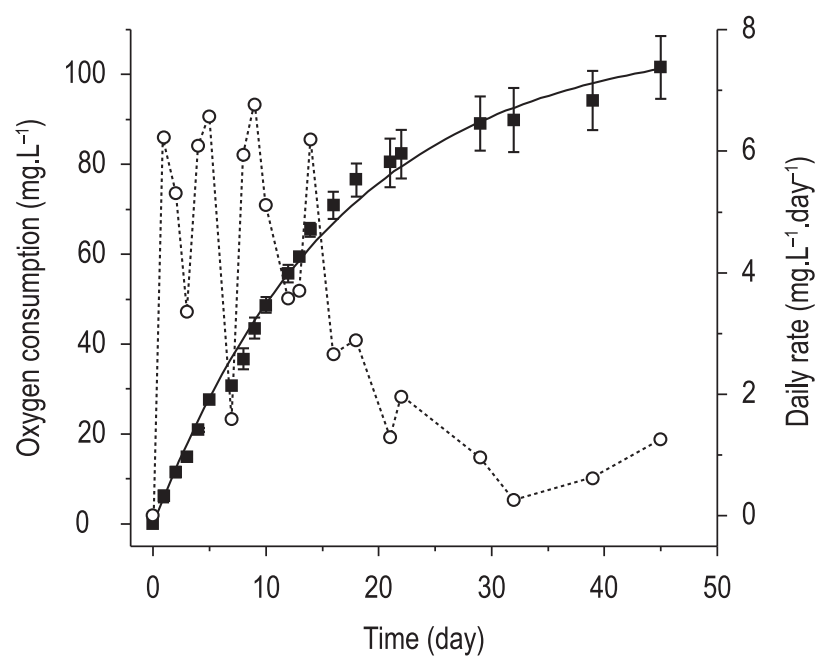

Figure 2. Kinetics of the Miriophyllum aquaticum leachate decreases (on organic and inorganic carbon basis) under aerobic (A, B) and anaerobic conditions (C, D). Daily rates and kinetic of oxygen consumption from aerobic decomposition of $M$. aquaticum leachate (E). 
Table 1. Kinetic model parameterizations. Where: $\mathrm{DOC}_{\mathrm{i}}=$ initial concentration of leachate (on organic carbon basis); $\mathrm{ROC}=$ refractory organic carbon; $\mathrm{MC}=$ mineralized organic carbon; $\mathrm{DIC}=$ dissolved inorganic carbon; $\mathrm{OC}_{\mathrm{MAX}}=$ maximum amount of consumed oxygen. $\mathrm{t}_{1 / 2}=$ half-life times; $\mathrm{k}=$ reaction rate (mass loss or deoxygenation).

\begin{tabular}{|c|c|c|c|c|}
\hline & \multicolumn{2}{|c|}{ Aerobic } & \multicolumn{2}{|c|}{ Anaerobic } \\
\hline & S. molesta & M. aquaticum & S. molesta & M. aquaticum \\
\hline $\mathrm{DOC}_{\mathrm{i}}\left(\mathrm{mg} \cdot \mathrm{L}^{-1}\right)$ & 118.4 & 101.4 & 118.4 & 101.4 \\
\hline $\mathrm{ROC}\left(\mathrm{mg} \cdot \mathrm{L}^{-1}\right)$ & 8.6 & 9.6 & 8.2 & 5.4 \\
\hline$M C\left(m g \cdot L^{-1}\right)$ & 109.8 & 91.8 & 110.2 & 96.1 \\
\hline $\mathrm{k}_{\mathrm{T}}\left(\right.$ day $\left.^{-1}\right)$ & 0.21 & 0.20 & 0.18 & 0.15 \\
\hline$r^{2}$ & 0.97 & 0.94 & 0.93 & 0.94 \\
\hline$t_{1 / 2}$ (day) & 3.3 & 3.5 & 3.8 & 4.6 \\
\hline DIC $\left(m g \cdot L^{-1}\right)$ & 14.3 & 4.0 & 13.8 & 4.8 \\
\hline $\mathrm{CO}_{\mathrm{MAX}}\left(\mathrm{mg} \cdot \mathrm{L}^{-1}\right)$ & 115.5 & 108.6 & - & - \\
\hline $\mathrm{k}_{\mathrm{D}}\left(\right.$ day $\left.^{-1}\right)$ & 0.056 & 0.060 & - & - \\
\hline$r^{2}$ & 0.98 & 0.99 & - & - \\
\hline $\mathrm{t}_{1 / 2}$ (day) & 12.4 & 11.6 & - & - \\
\hline $\mathrm{O} / \mathrm{C}$ & 1.05 & 1.18 & - & - \\
\hline
\end{tabular}

\section{Discussion}

The coefficients of determination $\left(\mathrm{r}^{2}\right)$ presented high values (Table 1 ), thus suggesting that the models employed (Equation 1 to 6) were appropriate. The results indicated that the overall mass loss (i.e., hydrosoluble compounds) from leaching processes was larger for $S$. molesta (Table 1). A meta-analysis that considered the decomposition of several macrophytes species has shown the existence of a considerable variability in their percentage of leachate material (range: 8.571.6\%; Bianchini Junior, 2003). According to Bianchini Junior (2003), this variability is associated with several factors such as detritus quality (chemical composition), phenological state of the plant and proportion of structural components (e.g., cell wall fraction) and protoplasmic fractions. The levels of leachate material suggest that, compared to $S$. molesta, detritus from $M$. aquaticum might contribute more to the particulate organic matter stocks of the Monjolinho Reservoir, due to the lower quantity of hydrosoluble matter of this species. However, other studies suggest that Myriophyllum, on average, has a particulate recalcitrant matter (三fibers) decomposition coefficient two times higher than Salvinia (Godshalk and Wetzel, 1978; Campos Junior, 1998; Cunha-Santino and Bianchini Junior, 2000). The combination of these characteristics suggests that, for this reservoir, Salvinia contribute more, both in COD formation (i.e., higher leaching potential) and sediment colmatation (owing the lower fiber loss mass coefficient). Moreover, it is often the description of the allelopathic activity of exudates from macrophytes (e.g., Gross et al., 2003).

For both leachates, the mineralization processes were faster in aerobic conditions (Table 1). It has been reported that aerobic processes act on a larger spectrum of organic matter and, in general, they perform faster than anaerobic processes (Bianchini Junior, 2003). Moreover, aerobic processes generate a higher quantity of ROC (average: $8.4 \%$ ) than anaerobic processes (average: $6.1 \%$ ), indicated by the remaining organic carbon concentration from both processes (Table 1). In this context, Peret and Bianchini Junior (2004), while evaluating aquatic macrophytes aerobic leaching, found that under aerobic conditions, $24.3 \%$ of dissolved organic carbon was converted in microorganism biomass and $24 \%$ in recalcitrant DOC. When comparing global mass loss coefficients $\left(\mathrm{k}_{\mathrm{T}}\right)$ from the leachates, $S$. molesta was higher for both aerobic and anaerobic processes. This can be explained by differences in chemical composition (e.g., levels of carbohydrates, nutrient concentration), suggesting that the hydrosoluble fraction of $S$. molesta is more labile than that of M. aquaticum. Leachates are formed by dissolution of polar composites (Moorhead et al., 1996) and generally are constituted by carbohydrates, polyphenols and nutrients, such as nitrogen, phosphorus, potassium and calcium (Best et al., 1990; Gupta et al., 1996; Nunes et al., 2007).

Evaluation of inorganic carbon (DIC) yield has shown that the incubations with $S$. molesta leaching was four times higher than $M$. aquaticum mineralization, regardless of conditions (i.e., aerobic versus anaerobic); Figures 1 and 2. Considering that 
MC production was on the same order of magnitude (Table 1) and that DIC concentrations $\left(\Sigma=\mathrm{CO}_{2}\right.$, $\mathrm{H}_{2} \mathrm{CO}_{3}, \mathrm{HCO}_{3}^{-}, \mathrm{CO}_{3}{ }^{2-}$ ) result from the balance between mineralization and mass loss processes (e.g., microbiologic assimilation and atmosphere diffusion), the findings of this study suggest that, in the Monjolinho Reservoir, $M$. aquaticum leaching can subsidize bacterioplankton growth (and eventually phytoplankton) more efficiently than S. molesta leaching processes.

The kinetics of oxygen consumption presented a similar pattern as other studies performed in aquatic macrophyte leachates (e.g., Peret and Bianchini Junior, 2004; Nunes et al., 2007). Leachates have a heterogeneous structure, comprised of labile and recalcitrant fractions. According to the oxygen consumption pattern, it is possible to infer labile fraction oxidations prevailed in the initial stages, generating elevated oxygen demand. The stoichiometric relationship $(\mathrm{O} / \mathrm{C})$ estimated from the kinetic parameters were: 1.05 (S. molesta leachate) and 1.18 ( $M$. aquaticum leachate); these values slightly lower than the mean obtained (1.39) by Bianchin Junior (2003), from the mineralization of different aquatic macrophyte species. The stoichiometric coefficients are related to the metabolic routes and to the density of microorganisms involved in the heterotrophic activity, thus the metabolic routes that predominate during the mineralization process dictate stoichiometric relationships. Heterogeneous substrates, such as leachates, present a global stoichiometry that result from the sum of the oxidation from different compounds that integrate the substrate and from the diverse interactions between the metabolic routes that participate in the process. Moreover, the relationship between oxygen and carbon is also dependent on temperature (Pacobahyba, 2002), detritus quality (Bianchini Junior, 2003), and on the amount of dissolved inorganic compounds; for example, nitrification processes can increase oxygen demand (Bowie et al., 1985). During mineralization of $M$. aquaticum leachate, a higher oxygen demand is used to the oxidation of nitrogen compounds in detriment of carbon (i.e., 2-fold) and the chemical oxidations represented only $1 \%$ of total oxygen uptake from mineralization process (Nunes et al., 2007). The values of $k_{D}$ determined in this study were on the same order of magnitude as those obtained by Peret and Bianchini Junior (2004) for the leachate of seven different aquatic macrophyte species. Studies performed with integral aquatic plant detritus (Cunha and Bianchini Junior, 1998;
Farjalla et al., 1999; Bitar and Bianchini Junior, 2002) found a mean deoxygenation coefficient of 0.18 day $^{-1}$ (half-life time $=3.8$ days).

These results suggest that the resources considered were mineralized intensively, where the catabolic processes (i.e., respiration) prevailed upon the production of recalcitrant organic carbon (immobilization) due to the labile nature of the leachate compounds, which are generated from the cytoplasm fractions of aquatic macrophytes (Bianchini Junior, 2003). Thus, depending on the biomass of $S$. molesta and $M$. aquaticum and on the water residence time of Monjolinho Reservoir, the mineralization of labile leachate fractions can generate great short-term pressures on the balance of dissolved oxygen, principally on the senescence stage of macrophyte populations, and also, contribute to the production of dissolved humic substances.

\section{Acknowledgements}

The authors thank CNPq (processes $n^{\circ} 140413 / 2003-0$ and 300959/2004-4) for the financial support of this work and also for the scholarships granted.

\section{References}

BASTARDO, H. 1981. Actividad microbiana durante la descomposición de gramíneas tropicales en sabanas inundables. Acta Biológica Venezuélica, vol. 11, no. 2, p. 149-168.

BEST, EPH., DASSEN, JHA., BOON, JJ. and WIEGERS, G. 1990. Studies on decomposition of Ceratophyllum demersum litter under laboratory and field conditions: losses of dry mass and nutrients, qualitative changes in inorganic compounds and consequences for ambient water and sediments. Hydrobiologia, vol. 194, no. 2, p. 91-114. http:// dx.doi.org/10.1007/BF00028411

BIANCHINI JUNIOR, I. 2003. Modelos de crescimento e decomposição de macrófitas aquáticas. In THOMAZ, SM. and BINI, LM., eds. Ecologia e manejo de macrófitas aquáticas. Maringá: EDUEM. p. $85-126$.

BITAR, AL. and BIANCHINI JUNIOR, I. 2002. Mineralization essays of some organic resources of aquatic systems. Brazilian Journal of Biology, vol. 62, no. 4A, p. 557-564. http://dx.doi.org/10.1590/ S1519-69842002000400001

BOWIE, GL., MILLS, WB., PORCELLA, DB., CAMPBELL, CL., PAGENKOPF, JR., RUPP, GL., JOHNSON, KM., CHAN, PWH. and GHERINI, SA. 1985. Rates, constants, and kinetics formulations in surface water quality modeling. 2th ed. Athens: U. S. Government Printing Office. 455p. EPA/600/385/040. U. S. Environmental Protection Agency. 
CAMARGO, AF. and ESTEVES, FA. 1995. Biomass and productivity of aquatic macrophytes in Brasilian lacustrine ecosystems. In TUNDISI, JG., BICUDO, CEM. and MATSUMURA-TUNDISI, T., eds. Limnology in Brazil. Rio de Janeiro: ABC/SBL. p. 137-149.

CAMPOS JUNIOR, JJF. 1998. Contribuição ao estudo da decomposição de macrófitas aquáticas da lagoa do Infernão: processo anaeróbio. São Carlos: Universidade Federal de São Carlos. 130 p. [Dissertação de Mestrado em Ecologia e Recursos Naturais].

CUNHA, MB. and BIANCHINI JUNIOR, I. 1998. Mineralização aeróbia de Cabomba piauhyensis e Scirpus cubensis. Acta Limnologia Brasiliensia, vol. 10, no. 1, p. 81-91.

CUNHA-SANTINO, MB. and BIANCHINI JUNIOR, I. 2000. Decomposição aeróbia e anaeróbia de Salvinia auriculata Aubl. da lagoa do Infernão. In SANTOS, JE. and PIRES, JSR., eds. Estudos Integrados em Ecossistemas - Estação Ecológica de Jataí. São Carlos: RiMa. vol. 2, p. 631-643.

CUNHA-SANTINO, MB. and BIANCHINI JUNIOR, I. 2003. Oxygen consumption during mineralization of organic compounds in water samples from a small sub-tropical reservoir (Brazil). Brazilian Archives of Biology and Technology, vol. 46, no. 4, p. 723-729. http://dx.doi.org/10.1590/S151689132003000400027

FARJALLA, VF., MARINHO, CC. and ESTEVES, FA. 1999. Uptake of oxygen in the initial stages of decomposition of aquatic macrophytes and detritus from terrestrial vegetation in a tropical coastal lagoon. Acta Limnologia Brasiliensia, vol. 11, no. 2, p. $185-193$.

GODSHALK, GL. and WETZEL, RG. 1978. Decomposition of aquatic angiosperms. II. Particulate contents. Aquatic Botany, vol. 1, p. 301-327.

GROSS, EM, ERHARD, D. and IVÁNYI, E. 2003. Allelopathic activity of Ceratophyllum demersum L. and Najas marina ssp. intermedia (Wolfgang) Casper. Hydrobiologia, vol. 506-509, no. 1-3, p. 583-589. http://dx.doi.org/10.1023/ B:HYDR.0000008539.32622.91

GUPTA, MK., SHRIVASTAVA, P. and SHINGAL, PK. 1996. Decomposition of young water hyacinth leaves in lake water. Hydrobiologia, vol. 335, no. 1, p. 33-41. http://dx.doi.org/10.1007/BF00013680

HENRY-SILVA, GG, PEZZATO, MM. and CAMARGO, AFM. 2008. Growth of free-floating aquatic macrophytes in different concentrations of nutrients. Hydrobiologia, v. 610, no. 1, p. 153-160. http://dx.doi.org/10.1007/s10750-008-9430-0

HUSSNER, A., MEYER, C. and BUSCH, J. 2009. The influence of water level and nutrient availability on growth and root system development of Myriophyllum aquaticum. Weed Research, vol. 49, p. 73-80. http:// dx.doi.org/10.1111/j.1365-3180.2008.00667.x

MARINELLI, CE., MORETTO, EM., BRUCHA, G. and LUCCA, JV. 2000. Limnologia. In Espíndola, ELG., Silva, JSV., Marinelli, CE. and Abdon, MM., eds. A Bacia Hidrográfica do Rio do Monjolinho. São Carlos: RiMa Editora. p. 133-149.

MITCHELL, DS. and TUR, NM. 1975. The growth of Salvinia molesta ( $S$. auriculata Auct.) in laboratory and natural conditions. Journal of Applied Ecology, vol. 12, no. 1, p. 213-225. http://dx.doi. org/10.2307/2401730

MOODY, ML. and LES, DH. 2010. Systematics of the aquatic angiosperm genus Myriophyllym (HALORAGACEAE). Systematic Botany, vol. 35, no. 1, p. 121-139. http://dx.doi. org/10.1600/036364410790862470

MØller, J., Miller, M. and KJØLLER, A. 1999. Fungalbacterial interaction on beech leaves: influence on decomposition and dissolved organic carbon quality. Soil Biology \& Biochemistry, vol. 31, no. 3, p. 367-374. http://dx.doi.org/10.1016/S00380717(98)00138-2

MOORHEAD, DL., SINSABAUGH, RL., LINKINS, AE. and REYNOLDS, JF. 1996. Decomposition processes: modeling approaches and applications. Science of the Total Environment, vol. 183, no. 1-2, p. 137-149. http://dx.doi.org/10.1016/00489697(95)04974-6

NOGUEIRA, MG. and MATSUMURA-TUNDISI, T. 1994. Limnologia de um sistema raso (represa do Monjolinho - São Carlos, SP). I - Dinâmica das variáveis físicas e químicas. Revista Brasileira de Biologia, vol. 54, no. 1, p. 147-159.

NOTARE, M. 1992. Plantas hidrófilas e seu cultivo em aquário. Rio de Janeiro: Editora Sulamérica/Flora Bleher. 238 p.

NUNES, MF., CUNHA-SANTINO, MB. and BIANCHINI JUNIOR, I. 2007. Aerobic mineralization of carbon and nitrogen from Myriophyllum aquaticum (Vell.) Verdc. leachate. Acta Limnologia Brasiliensia, vol. 19, no. 3, p. 285-293.

NUNES, MF., CUNHA-SANTINO, MB. and BIANCHINI JUNIOR, I. 2011. Xylanase and cellulase activities during anaerobic decomposition of three aquatic macrophytes. Brazilian Journal of Microbiology, vol. 42, no. 1, p. 75-83. http://dx.doi. org/10.1590/S1517-83822011000100010

ORCHARD, AE. 1981. A revision of South American Myriophyllum (Haloragaceae), and its repercussion on some Australian and North American species. Brunonia, vol.4, p. 27-65. http://dx.doi.org/10.1071/ BRU9810027

PACOBAHYBA, LD. 2002. Decomposição de Straurastrum c.f. iversenii Nygaard var. americanum: efeitos da qualidade do recurso, da disponibilidade de 
oxigênio e da temperatura. São Carlos: Universidade Federal de São Carlos. 118 p. [Tese de Doutorado em Ecologia e Recursos Naturais].

PENNING, WE., MJELDE, M., DUDLEY, B., HELLSTEN, S., HANGANU, J., KOLADA, A., VAN DEN BERG, M., POIKANE, S., PHILLIPS, G., WILLBY, N. and ECKE, F. 2008. Classifying aquatic macrophytes as indicators of eutrophication in European lakes. Aquatic Ecology, vol. 42, no. 2, p. 237-251. http://dx.doi.org/10.1007/s10452008-9182-y

PERET, AM. and BIANCHINI JUNIOR, I. 2004. Stoichiometry of aerobic mineralization $(\mathrm{O} / \mathrm{C})$ of aquatic macrophytes leachate from a tropical lagoon (São Paulo - Brazil). Hydrobiologia, vol. 528, no. 1-3, p. 167-178.

PRESS, WH., TEUKOLSKY, SA., VETTERLING, WT. and FLANNERY, BP. 1993. Numerical recipes in C: the art of scientific computing. New York: Cambridge University Press. 994 p.

SILVA, GHG. 2001. Utilização de macrófitas aquáticas flutuantes (Eichhornia crassipes, Pistia stratiotes e Salvinia molesta) no tratamento de efluentes de piscicultura e possibilidades de aproveitamento da biomassa vegetal. Jaboticabal: Universidade Estadual Paulista. 77 p. [Dissertação de Mestrado em Aqüicultura em Águas Continentais].

STODEREGGER, KE. and HERNDL, GJ. 1998. Production and release of bacterial capsular material and its subsequent utilization by marine bacterioplankton. Limnology and Oceanography, vol. 43, no. 5, p. 877-884. http://dx.doi.org/10.4319/ lo.1998.43.5.0877

SWIFT, MJ., HEAL, DW. and ANDERSON, JM. 1979. Studies in ecology. Decomposition in terrestrial ecosystems. Oxford: Blackwell. 371 p.

WARD, AK. and JOHNSON, MD. 1996. Heterotrophic microorganisms. In HAUER, FR. and LAMBERTI, GA., eds. Methods in stream ecology. San Diego: Academic Press. p. 233-268.

WETZEL, RG. 2001. Limnology-Lake and river ecosystems. San Diego: Academic Press/Elsevier. $1006 \mathrm{p}$. 